\title{
PEMAHAMAN PRAKTISI BMT \\ DI YOGYAKARTA TERHADAP PSAKNO. 59 \\ (AKUNTANSI PERBANKAN SYARIAH) PENGAKUAN \\ DAN PENGUKURAN PRODUK FUNDING
}

\author{
Oleb: Eny Iroh Hayat*
}

\section{Abstract}

The objective of this research is to explore BMT practitioners' understanding about the SFAS No. 59 on Shariate Banking Accountancy for funding product. For this reason, the research is conducted using descriptive method. Field researcb using quantitative approach is also used. However, qualitative approach is also used to explore and to clarify as well as to compare between the concept and the real situation. The population used in this study is member of PUSKOPSYAH DIY, and the subjects of this research are the managers and accounting staff of these $B M T$ s. The sample consists of $30 \%$ of 80 active members. However, since the magnitude of each sub-population is different, proportional sampling metbod is used to determine the number of sample taken from each sub-population, and purposive sampling method is used as the sampling method. The independent variables used in this research are age, educational background, the length of time working in BMT, and the frequency of training or workshop joined by the subjects. Meanwhile, the dependent variable in this research is the BMT practitioners' understanding about SFAS No. 59 for funding product. Data gathering method used in this research was questionnaire, field observation and interview. Meanwbile, data analysis for this study includes descriptive statistical analysis and inferential statistical analysis.

مستخنص

هذا البحث بحث ميداني يحاول على بيان موقف الفاعلين في الشركة " يت اللال والتمويل" من

.PSAK وني هذه الهحاولة يستخدم الباحثة الطريقة الإحصايثة (الكمية) من ناحية، وانطريقة النوعية في سمبيل كثف بين المفهوم المثالي والواقع من ناحية أخرى. الذي يهتم به البحث هو بيت المال والتمويل من أعضاء PUSKOPSYAH بيوجياكرتا على الأخص مدير الشركة ومحاسيها أو المعرضض للفحاسبة. والجدير بالعلم أن هذا البحث يتحدد بحثها على ثلاثين بالمئة من ثمائين أعضائها. ولتحديد أخذ العينات واختيارها فاختارت الباحثة العينات المتناسبة والعينات العشوائية نتيجة لاختلاف عدد العناصر

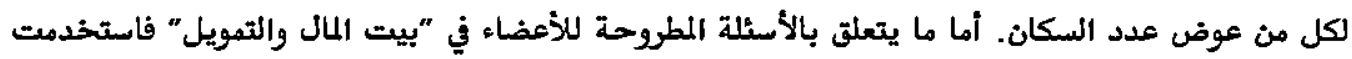

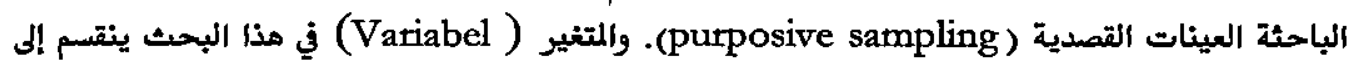
@yahoo.com

Alumni Ekonomi Islam Magister Studi Islam Universitas Islam Indonesia. Email:enys_uin 
قسمين. الأول المتغير المطلق أعني ما يتكون من سن الشخص وطبقات تربيته وزمان عمله في الشركة " يت المال والتمويل. أما الثاني فهو المتغير المقيد. وهو ما يتعلق بنغهوم العاملين من من 59 PSAK

Keywords: akuntansi, PSAK No. 59, pemahaman, Praktisi BMT

\section{A. Pendahuluan}

Munculnya lembaga keuangan syariah alternatif didorong oleh adanya kendala dari perbankan syariah dalam menjangkau kalangan bawah. Komitmen untuk membantu meningkatkan derajat hidup masyarakat bawah mengalami kendala baik dari sisi hukum dan praktis. Dari sisi hukum, prosedur peminjaman bank umum dengan BPRS sama, begitu juga dari sisi teknis. Padahal inilah kendala utama pengusaha kecil, sehingga harapan besar pada perbankan syariah hanya menjadi realita.

BMT (Baitul Mâl wat-Tamwîl) sebagai salah satu lembaga keuangan syariah alternatif, merupakan lembaga yang tidak saja business oriented tetapi juga social oriented. ${ }^{1}$ BMT merupakan lembaga keuangan yang bersifat mikro, yang bergerak di kalangan ekonomi bawah. Karena beroperasi dengan pola syariah, sudah barang tentu mekanisme kontrolnya tidak saja dari aspek ekonomi saja atau kontrol dari luar, tetapi agama atau akidah menjadi faktor pengontrol yang lebih dominan.

Sampai akhir 2005 lalu, jumlah lembaga keuangan mikro syariah Baitul Mâl wat tamuzl (BMT) di Indonesia telah mencapai lebih dari 3.000.2 Sedangkan untuk Daerah Istimewa Yogyakarta sendiri, menurut data dari PUSKOPSYAH per Agustus 2006 sudah berdiri sebanyak $82 \mathrm{BMT}^{3}$ namun jumlah ini belum termasuk yang berada di luar PUSKOPSYAH.

Kendati lahirnya banyak BMT di tanah air dapat dipahami sebagai fenomena menggembirakan, bukan berarti proses ini berjalan mulus. Banyak permasalahan penting (crucial problems) yang perlu segera dipecahkan untuk dicarikan solusinya. Salah satu permasalahan itu adalah dalam hal implementasi prinsip-prinsip syariat Islam dalam bidang akuntansi. Keberadaan akuntansi dalam lembaga keuangan merupakan hal yang sangat vital, karena hampir setiap hari lembaga-lembaga keuangan senantiasa berhubungan dengan transaksi-transaksi keuangan yang memerlukan suatu pedoman. 74.

${ }^{1}$ Muhammad Ridwan, Manajemen Baitul Mal wat Tamwil, (Yogyakatta: UII Press. 2004), hal. 73-

${ }^{2}$ Dikutip dari www.tepublika.co.id, diakses pada April 2006

${ }^{3}$ Sumber: Puskopsyah DIY 
Dengan demikian, sudah merupakan hal yang wajar bahwa akuntansi dibutuhkan agar setiap transaksi ekonomi yang dilakukan dalam lembaga itu dapat tercatat dan terkontrol dengan baik. Dengan akuntansi, hak berbagai pibak yang terlibat dapat terlindungi secara adil. ${ }^{4}$

Secara legal dan formal, BMT berbadan hukum koperasi. Namun standard akuntansi yang digunakan berbeda-beda. ${ }^{5}$ Ada yang memakai akuntansi koperasi, akuntansi perseroan terbatas, bahkan ada yang memakai standard akuntansi bank. Karena biasanya BMT berbadan hukum koperasi, BMT menggunakan PSAK No. 27 tentang Akuntansi Koperasi sebagai standar akuntansinya. Mengenai hal ini Triyuwono berpandangan bahwa bentuk koperasi yang berwatak sosial memberikan wama yang sama pada praktilk, atau standar akuntansi keuangan koperasi. ${ }^{6} \mathrm{Namun}$, meski akuntansi berada dalam wadah koperasi yang berwatak sosial, ia masih diwarnai oleh watak aslinya yang kapitalistik (lebih mementingkan anggota koperasi yang tentu saja kurang sesuai dengan karakteristik lembaga keuangan syariah.

Sementara itu Amin Aziz, Ketua Pusat Inkubasi Usaha Kecil (PINBUK) mengakui bahwa operasional BMT memang sudah sangat mirip dengan bank dan sudah berbeda dari koperasi. Bila koperasi hanya menerima tabungan dan meminjamkan dana hanya untuk anggotanya, maka BMT banyak yang melayani di luar anggota. ${ }^{7}$ Hal senada juga dikemukakan Yaya. ${ }^{8}$ Ia menyatakan bahwa sebagai lembaga yang berdasarkan ajaran Islam, BMT dan Bank Syari'ah beroperasi berdasarkan kaidah fiqih yang sama. Baik BMT maupun Bank Syari'ah mesti mendasari operasinya berdasar fatwa Dewan Syari'ah Nasional (DSN) yang memiliki kewenangan dalam menentukan dasar hukum suatu transaksi. Oleh karenanya dalam praktik di lapangan, tidak ada perbedaan antara transaksi di BMT maupun transaksi di Bank Syari'ah.

Jadi, karena realitanya operasional BMT tidak berbeda dengan bank maka secara substantif BMT dapat disamakan dengan bank. Oleh karena itu, kiranya kurang tepat

${ }^{4}$ Hertanto Widodo dkk, Pedoman Akuntansi Syariat Panduan Praktis Operasional Baitul Mal Wat Tamwil, (Bandung: Mizan, 2000), hal 58.

5 “BMT' Perlu Standard Akuntansi" dikutip dari ympurepublka,co.id, diakses tanggal 5 April 2006.

"Iwan Tryuwono, "Akuntansi Syari'ah dan Koperasi Mencari Bentuk Dalam Metafora Amanah", Jurnal Akuntansi dan Auditing Indonesia, Volume 1 No.1 Mei 1997, hal. 38-42.

${ }^{7}$ Amin Aziz dalam "Jangan Paksa BMT' Besar Jadi BPRS" dikutip dari unm. republika.coid, diakses tanggal 5 April 2006.

${ }^{8}$ Rizal Yaya, “Mengkritisi Konsep Akuntansi Keuangan bagi Lembaga Keuangan Mikro Syari'ah”. Workshop Merancang Format Akuntansi Kexangan Bagi Lembaga Kewangan Mikro Syariah di Hotel Inna Garuda-Yogyakarta tanggal 9-12 Agustus 2004 oleh Pusat Pengembangan Ekonomi (PPE) Universitas Muhammadiyah Yogyakarta dan BMT Hidayatul Muamalah Wonogiri, hal. 7-8. 
apabila BMT menggunakan standar akuntansi PSAK 27. BMT lebih tepat menggunakan PSAK No. 59 tentang Akuntansi Perbankan Syari'ah. Sebagaimana yang diungkapkan Adnan, meskipun secara formal konsep akuntansi lembaga keuangan mikro syari'ah belum disusun namun secara normatif dapat mengacu pada standar yang sementara sudah ada yaitu PSAK No.59 dan kerangka dasar penyusunan dan penyajian laporan keuangan.'

Apa yang dicermati dalam penelitian ini bukan merupakan persoalan lapangan semata, melainkan juga persoalan kepatuhan terhadap syari'ah pada lembaga keuangan syariah terutama pada BMT di Yogyakarta. Jadi, berangkat dari fenomena di atas, sangat menarik untuk meneliti lebih lanjut mengenai pemahaman praktisi BMT di Yogyakarta terhadap PSAK No. 59 Akuntansi Perbankan Syariah pengakuan dan pengukuran produk funding, serta bagaimana hubungan usia, lama bekerja di BMT, latar belakang pendidikan dan frekuensi mengikuti pelatihan, seminat dan atau lainnya terhadap pemahaman praktisi BMT pada konsep PSAK No. 59 pengakuan dan pengukuran produk frunding. Hal ini dikarenakan pemahaman dari para praktisi BMT (terutama manajer dan akuntannya), akan berimbas pada kebijakan dan.juga teknik akuntansi yang digunakan. Karenanya, penelitian ini akan menjadi awal untuk mengetahui seberapa jauh pemahaman praktisi BMT di Yogyakarta terhadap PSAK 59 dan kemungkinan penerapannya.

Jadi, mengacu pada permasalahan tersebut di atas, artikel ini bertujuan untuk memberikan suatu deskripsi mengenai bagaimana pemahaman praktisi BMT-BMT di Yogyakarta terhadap Pernyataan Standar Akuntansi Keuangan (PSAK) No. 59 pengakuan dan pengukuran produk funding dan juga untuk mengetahui bagaimana hubungan antara usia, lama bekerja di BMT, latar belakang pendidikan dan frekuensi mengikuti pelatihan, seminat dan atau lainnya terhadap pemahaman praktisi BMT pada konsep PSAK 59 pengakuan dan pengukuran produk funding.

\section{B. Tinjauan Pustaka}

Islam sebagai ideologi tentunya sangat sarat dengan nilai. Dengan demikian, bangunan akuntansi yang betlaku dalam masyarakat Islam tentunya harus menyesuai-

9 Akhyar Adnan, Kritik atas Konsep Akuntansi Keuangan Lembaga Syariah Milkso dalam Workshop Merancang Format Akuntansi Keuangan Bagi Lembaga Keuangan Mikro Syariab di Hotel Inna GarudaYogyakarta tanggal 9-12 Agustus 2004 oleh Pusat Pengembangan Ekonomi (PPE) Universitas Muhammadiyah Yogyakarta dan BMT Hidayatul Muamalah Wonogiri, hal. 10.

${ }^{10}$ Muhamad, Pengantar Akuntansi Syariab, (Jakarta: Salemba Empat, 2002), hal.10. 
kan diri dengan karakteristik Islam itu sendiri. Sehingga universalitas ajaran Islam tentunya dapat dijadikan acuan secata menyeluruh bagi semua kelompok masyarakat. ${ }^{10}$

Secara umum, akuntansi dapat didefinisikan sebagai sistem informasi yang menghasilkan laporan kepada pihak-pihak yang berkepentingan mengenai aktifitas ekonomi dan kondisi suatu usaha. ${ }^{11}$ Sedangkan menurut literatur-literatur yang ada, terdapat beberapa pengettian akuntansi. Menurut American Institute of Certified Public Accountant (AICPA), akuntansi adalah seni pencatatan, penggolongan, dan pengikhtisaran dengan cara tertentu dan dalam ukuran moneter, transaksi, dan kejadiankejadian yang umumnya bersifat keuangan dan termasuk menafsirkan hasil-hasilnya.

Tujuan dari akuntansi adalah memberi informasi kepada para pemakai dalam rangka pengambilan keputusan. Tujuan umum dari akuntansi adalah memberikan gambaran kepada para pemakai tentang kinezja usaha, posisi keuangan, dan arus kas sebuah organisasi dalam periode tertentu. Dari tujuan umum ini, informasi akuntansi dapat dipergunakan untuk tujuan khusus, misalnya untuk menghitung kewajiban pajak dan kemungkinan dapat dijadikan dasar untuk menghitung kewajiban zakat.

Akuntansi merupakan domain "muamalah" dalam kajian Islam. Artinya diserahkan kepada akal pikiran manusia untuk mengembangkannya. Namun karena pentingnya permasalahan ini maka Allah SWT bahkan memberikannya tempat dalam kitab suci Al-Quran yang digunakan sebagai dasar munculnya akuntansi yang sesuai syariat Islam yaitu Surat Al-Baqarah: $282 .{ }^{12} \mathrm{Dalam}$ ayat ini, dapat diketahui bahwa tekanan Islam dalam kewajiban melakukan pencatatan adalah menjadi bukti dilakukannya transaksi (muamalah) yang menjadi dasar nantinya dalam menyelesaikan persoalan selanjutnya, serta menjaga agar tidak terjadi manipulasi, atau penipuan baik dalam transaksi maupun hasil dari transaksi itu (laba) ${ }^{13}$ Dari ayat ini juga, Muhammad melansir ada tiga kandungan prinsip umum akuntansi syariah yaitu; prinsip pertanggungjawaban, prinsip keadilan dan prinsip kebenaran. ${ }^{14}$

${ }^{11}$ Carl S. Warten, et. al, Accounting 21th Edition, alih bahasa Aria Farahmita, dkk. Pengantar Akuntansi Edisi 21 (Buks 1), Jakarta (Salemba Empat, 2005), hal. 24-27.

${ }^{12}$ Al-Quran dan Terjemahnya, Depag RI.

${ }^{13}$ Sofyan Syafri Hamap, Akuntansi Islam, (Jakarta: Bumi Aksara, 1997), hal. 142.

${ }^{14}$ Muhammad, Prinsip-prinsip Akuntansi dalam Al-Qur'an, (Yogyakarta: UII Press, 2000) hal 42. 
Dalam Accounting Issues in Islamic Banking, ${ }^{15}$ seperti yang dikutip Muhammad, menyebutkan bahwa tujuan informasi akuntansi dalam lembaga keuangan syariah muncul karena dua alasan, yaitu:

1. Lembaga Keuangan syariah dijalankan dengan kerangka syariah sebagai akibat dari hakikat transaksi yang berbeda dengan lembaga keuangan konvensional.

2. Pengguna informasi akuntansi pada lembaga keuangan syatiah adalah berbeda dengan pengguna informasi akuntansi di lembaga keuangan konvensional.

Akhir dari siklus akuntansi adalah tersedianya Laporan Keuangan. Laporan keuangan dikatakan memiliki kualitas tinggi apabila memenuhi persyaratan kualitatif laporan keuangan yaitu mudah dipahami, andal, relevan, dan dapat diperbandingkan. Apabila suatu usaha yang berkepentingan dengan orang banyak mencatat dan melaporkan data keuangan seperti keinginannya sendiri, maka perbandingan di antara usaha yang sejenis akan sulit, bahkan tidak mungkin. ${ }^{16}$ Oleh karena itu, dalam dunia usaha diperlukan praktik akuntansi yang sesuai dengan standar akuntansi yang berlaku umum, ${ }^{17}$ sementara di luar itu bisa saja tanpa standac. Di Indonesia, hukum yang mengatur bagaimana mengukur/menilai, mengolah dan mengkomunikasikan informasi akuntansi terdapat di dalam SAK (Standar Akuntansi Keuangan) yang berisi tentang prinsip akuntansi yang betlaku umum. Sedangkan untuk hal-hal yang bersifat khusus digunakan Pernyataan Standar Akuntansi Keuangan (PSAK). ${ }^{18}$

Berkaitan dengan standar, Edey seperti yang dikutip Muhammad menyatakan. bahwa ketentuan yang terdapat dalam standar bextujuan untuk: ${ }^{19}$

1. Mengharuskan akuntan untuk menginformasikan apa yang dilakukan dengan mengungkapkan metode dan kebijakan akuntansi yang digunakan.

2. Mendotong tercapainya keseragaman (uniformity) penyajian laporan keuangan.

3. Mendorong diungkapkannya hal-hal spesifik yang pengguna informasi mungkin memerlukannya untuk pengambilan keputusan.

15 "Institute of Islamic Banking and Insurance, Accounting Issues in Islamic Banking", dalam Muhamad, Pengantar, hal. 103.

${ }^{16}$ Carl S. Warren, Accounting, hal. 16.

${ }^{17}$ Mursyidi, Akuntansi Zakat Kontemporer, (Bandung. Remaja Rosda Karya, 2003), hal. 14.

${ }^{18}$ Charles T. Horngren, Accounting, hal. 7.

${ }^{19}$ Edey dalam Muhamad, Pengantar Akuntansi Syariah, Edisi 2, (Jakarta: Salemba Empat, 2005), hall 201. 
4. Mensyaratkan diungkapkannya keputusan eksplisit dan implisit tentang penilaian asset yang disetujui dan tentang penentuan pendapatan.

Jadi dalam dunia usaha diperlukan standar akuntansi yang sesuai dengan standar akuntansi yang berlaku umum. ${ }^{20}$ PSAK 59 tentang akuntansi perbankan syari'ah yang disahkan oleh Dewan Standar Akuntansi Keuangan pada tanggal 1 Mei 2002 merupakan salah satu bentuk wacana tentang akuntansi syariah praktis di Indonesia. Akuntansi syariah, dalam hal ini PSAK No. 59, bukan hanya untuk menyediakan informasi untuk decision making tapi juga menjamin bahwa organisasi mematuhi prinsip dan aturan syariah serta tujuan socio economic. ${ }^{21}$ Hal ini merupakan cerminan karakteristik lembaga keuangan syariah. Laporan keuangan akuntansi syari’ah praksis juga ditujukan untuk pemakai yang sama dengan pemakai laporan keuangan akuntansi konvensional dengan tambahan untuk investor dana terikat, pembayar zakat, infaq, dan shadaqah serta Dewan Pengawas Syariah.

PSAK 59 berisi tentang pengakuan, pengukuran dan karakteristik produk-produk bank syariah seperti mudârabah, musyârakah, murâbahah, salam, istishnâ, wadîab, qardh, sharf, serta pengakuan dan pengukuran zakat. Selain itu PSAK 59 juga berisi tentang penyajian komponen-komponen Lapotan Keuangan Bank Syari'ah dan juga pengungkapan umum Laporan Keuangan. ${ }^{22}$

Dari sudut pandang perkembangan perbankan syariah dan lembaga-lembaga keuangan mikro syariah, dengan dikeluàrkannya Pernyataan Standar Akuntansi Keuangan (PSAK) No. 59 tentang Akuntansi Perbankan Syariah tersebut, dapat diharapkan sebagai instrumen yang dapat meningkatkan kepercayaan publik dalam menabung dan berbisnis dengan bank syariah maupun lembaga keuangan mikro syariah. Sementara itu jika dilihat dari iklim bisnis masyarakat Indonesia yang masih rendah tingkat integrasinya dengan nilai-nilai Islam, PSAK No. 59 dapat diharapkan sebagai ujung tombak baik dalam proses pengembangan bisnis yang islami maupun dalam pengembangan ilmu bisnis yang peduli pada moralitas, spirit agama, dan ke-

${ }^{20}$ Mutsyidi, Aketntansi, hal. 14.

${ }^{21}$ Dwi Ratmono, "Pengungkapan Islamic Values Dalam Pelaporan Keuangan Bank Syariah Paradigma Akuntansi Syariah Filosofis-Teoritis dan PSAK 59", Prosiding Simposium Nasional Sistem Ekonomi Islam II, Pusat Pengkajian Bisnis dan Ekonomi Islam Fakultas Ekonomi Universitas Brawijaya Malang, 28-29 Mei 2004, hal. 395.

${ }^{22}$ Lihat dalam Pemyataan Standar Akuntansi Keuangan No 59 Ikatan Akuntan Indonesia, Cet. I, Mei 2002, paragraf 1. 
pedulian sosial. ${ }^{25}$ Karenanya, faktor pemahaman praktisi BMT terhadap PSAK 59 mempunyai andil menuju ke sistem akuntansi yang bertanggung jawab dan berkeadilan.

\section{Metodologi Penelitian}

Penelitian ini menggunakan pendekatan kuantitatif. Namun demikian, untuk mengungkapkan dan memperjelas antara konsep dan realita pendekatan kualitatif juga akan digunakan. Pendekatan ini juga bisa menjelaskan pandangan mengenai persoalan akuntansi syariah di lembaga keuangan mikro syariah. Penelitian ini merupakan jenis penelitian lapangan (field research). Penelitian lapangan dilakukan dengan melakukan observasi dan wawancara terhadap manajer dan staf akuntansi dati BMT yang dijadikan sampel penelitian, sehingga dapat merepresentasikan dan mendeskripsikan seluruh BMT yang ada di Yogyakarta. Penelitian lapangan ini juga diarahkan pada upaya mencari kecenderungan-kecenderungan umum yang berkaitan dengan teknik operasional akuntansi syariah (PSAK 59) pada BMT di Yogyakarta.

Penelitian ini mempunyai sifat deskriptif, karena tujuan penelitian ini adalah berusaha memberi gambaran mengenai pemahaman praktisi BMT terhadap PSAK 59 pengakuan dan pengukuran produk funding. Selain itu penelitian ini juga berusaha menggambarkan atau menunjukkan adanya perhubungan (korelasi) antara variabelvariabel atau memberi gambaran sejauh mana dua atau lebih variabel kuantitatif berhubungan yang ditunjukkan dengan angka koefisien korelasi. ${ }^{24} \mathrm{Dalam}$ penelitian ini populasinya adalah BMT yang menjadi anggota PUSKOPSYAH di Daerah Istimewa Yogyakarta. Menurut data PUSKOPSYAH, hingga 31 Agustus 2006 jumlah anggota Puskopsyah BMT Mitra Nugraha tercatat sebanyak 80 BMT aktif yang tersebar di 5 subpopulasi kabupaten/kota. Menurut Gay seperti yang dikutip Husein Umar, ${ }^{25}$ menyatakan bahwa ukuran minimum sampel yang dapat diterima apabila didasarkan pada desain deskriptif adalah minimal 10\% dari populasi, dan untuk populasi yang relatif kecil minimal 20\%. Dalam penelitian ini diambil sebanyak $30 \%$ sampel.

Teknik pengambilan sampel yang digunakan adalah proportional sampling. Kemudian, untuk menentukan BMT mana saja yang akan digunakan sebagai sampel

${ }^{23}$ Dwi Ratmono, "Pengungkapan, hal. 395.

${ }^{24}$ Soehardi Sigit, Pengantar Metodologi Penelition Sosial Bisnis Manajemen, (Yogyakarta: Lukman Offset, 1999), hal. 99.

${ }^{25}$ Husein Umar, Riset Akuntansi, (Jakarta: Gramedia Pustaka Utama, 1998) hal.70. 
pada tiap-tiap subpopulasi digunakan simple random sampling, dan untuk menentukan siapa saja tesponden yang dipilih untuk mengisi angket/kuesioner digunakan purposive sampling. Dalam hal ini responden adalah praktisi BMT yang terdiri dari manajer dan staf akuntansinga.

Dalam penelitian ini yang menjadi variabel-variabel penelitian adalah: Variabel Bebas (Independent Variable) yang diberi simbol X, terdiri dati: Usia $\left(X_{1}\right)$; Latar belakang pendidikan $\left(X_{2}\right)$; Lama bekerja di institusi BMT $\left(X_{3}\right)$; dan Frekuensi mengikuti pelatihan,seminar atau kegiatan yang semacamnya $\left(X_{4}\right)$. Sedangkan Variabel Terikat (Dependent Variabel) yang diberi simbol Y, yaitu pemahaman praktisi BMT pada PSAK 59 pengakuan dan pengukuran produk funding.

Karena penelitian ini merupakan jenis penelitian lapangan yang mempunyai sifat desktiptif, teknik pengumpulan data dilakukan dengan menggunakan angket/ kuesioner, observasi, dan wawancara. Sedangkan teknik analisa data meliputi beberapa tahap, yaitu: 'pengolahan data yang mencakup kegiatan mengedit (editing) data dan mengkode (coding) data; tahap analisa data; dan tahap interpretasi data.

Analisa data menunjuk pada mengorganisasikan data kedalam susunan-susunan tertentu dalam rangka menginterpretasikan data. Dalam penelitian ini analisa data meliputi analisis statistik deskriptif dan analisis statistik inferensial. ${ }^{26}$ Analisis statistik deskriptif digunakan untuk menganalisa data dengan cara mendeskripsikan atau menggambarkan data dari angket yang telah terkumpul dengan cara membuat tabeltabel (tabulasi) serta perhitungan prosentase. Analisis ini digunakan untuk menjawab permasalahan pertama. Sedangkan analisis statistik inferensial dilakukan untuk mengukur tingkat hubungan antara variabel-variabel.

Dalam hubungan yang melibatkan lebih dari dua variabel, teknilk statistik yang digunakan adalah analisis korelasi ganda yang hasilnya adalah koefisien kotelasi ganda $(R)$ dan analisa korelasi parsial yang hasilnya adalah koefisien korelasi parsial $\left(r_{p}\right) \cdot{ }^{27}$ Untuk uji statistik koefisien korelasi ganda adalah dengan menggunakan $\mathrm{Uji}$ F dan uji statistik koefisien korelasi parsial adalah dengan menggunakan Uji t. ${ }^{28}$ Pada dasarnya uji $\mathrm{F}$ ini adalah pengujian terhadap $\mathrm{R}\left(r_{y y}\right.$, atau coefficient of multiple correlation $) .^{29}$ Dengan kata lain uji $\mathrm{F}$ digunakan untuk pengujian signifikansi $\mathbf{R}$.

${ }^{26}$ Sugiyono, Metode Penelitian Administrasi, Edisi 13 (Bandung: Alfabeta, 2005), hal. 169.

${ }^{27}$ Husaini Usman dan R. Pumomo Setiady Akbar, Pengantar Statistika, Jakarta: Bumi Aksara, 1995), hal. 253.

${ }^{28}$ Iqbal Hasan, Anatisa Data Penelition Dengan Statistik, (Jakarta: Bumi Aksara, 2005), (Jakarta: Bumi Aksara, 2005), hal. 80.

${ }^{29}$ Sanapiah Faisal, Fomat-format PeneEtian Sosial, (Jakarta: Raja Grafindo Persada, 2005), hal 235-237. 


\section{Analisa}

Sesuai hasil jawaban responden tethadap butir-butir pertanyaan dalam angket, secara umum (95.8\%) responden mempunyai tingkat pemahaman yang tinggi. $\mathrm{Hal}$ ini dapat dimungkinkan karena pada dasarnya teori-teori tentang produk funding yang terdiri dari tabungan mudârabah dan tabungan wadiab sudah dikenal dengan baik. Namun demikian, berdasarkan hasil dari angket ini pula ada beberapa hal yang cukup menarik untuk dicermati. Atas dasar jawaban responden, meskipun tingkat pemahaman praktisi BMT pada PSAK No. 59 tersebut pada kategori tinggi yaitu 95.8\% namun hanya $62.5 \%$ yang setuju bahwa standar akuntansi yang sesuai untuk BMT adalah PSAK No. 59. Sedangkan sisanya menganggap PSAK 59 tidak sesuai untuk BMT. Hal ini patut menjadi perhatian, karena di satu sisi mereka cukup paham terhadap PSAK 59 namun di sisi lain mereka kurang setuju dengan penerapan PSAK 59 di BMT. Hal ini bisa terjadi, sangat dimungkinkan karena belum tersosialisasikannya PSAK 59 ke pengelola BMT tersebut, sehingga meskipun praktisi BMT cukup paham namun karena belum ada political will dari pengelola dan juga tidak adanya aturan yang jelas mengenai pemberlakuan PSAK 59 di BMT, maka menyebabkan keengganan pengelola BMT untuk mengimplementasikan PSAK 59 tersebut di institusinya. Dari sini tergambar bahwa keberadaan PSAK 59 tersebut masih membutuhkan proses panjang untuk sampai ke implementasinya.

Selanjutnya, setelah diketahui bahwa tingkat pemahaman responden yang berada dalam kategori tinggi cukup besar, maka yang menjadi pertanyaan adalah: apakah usia, lamanya bekerja, latar belakang pendidikan, dan frekuensinya mengikuti pelatihan mempunyai hubungan dengan tingginya pemahaman responden terhadap PSAK 59 pengakuan dan pengukuran produk funding? Hasil ini tentunya sangat menarik untuk dikaji, karena berdasarkan observasi dan wawancara dengan responden diketahui bahwa sekitar $75 \%$ masih belum mengimplementasikan PSAK No. 59 di institusinya.

Hasil pengujian dengan menggunakan analisa korelasi ganda diperoleh koefisien korelasi ganda $(R)$ sebesar 0.682 . Interpretasi dari nilai $R$ ini adalah, variabelvariabel bebas yang terdiri dari umur, lamanya bekerja, latar belakang pendidikan, dan frekuensi mengikuti pelatihan, secara bersama-sama mempunyai keeratan hubungan yang cukup ${ }^{30}$ terhadap variabel terikat (pemahaman responden terhadap PSAK No. 59 pengakuan dan pengukuran produk funding). Selanjutnya dengan taraf signifikansi 5\% dan derajat kebebasan (df) 43 diperoleh $F_{\text {label }}$ sebesar 2,589. Karena 
$F_{\text {htang }}=9.368>F_{\text {tabel }}=2.589$, maka dapat disimpulkan bahwa variabel bebas secara bersamasama mempunyai hubungan yang signifikan terhadap variabel terikat.

Berdasarkan hasil analisa korelasi parsial, diketahui bahwa dalam penelitian ini, variabel latar belakang pendidikan merupakan variabel yang paling tinggi keeratan hubungannya dengan variabel pemahaman. Besarnya hubungan ini ditunjukkan dengan angka koefisien korelasi parsial $\left(r_{p}\right)$ sebesar 0.401. Kemudian diikuti oleh variabel usia sebesar 0.361 , kemudian variabel lama bekerja sebesar 0.326 , dan terakhir variabel yang mempunyai keeratan hubungan paling kecil adalah variabel frekuensi mengikuti pelatihan yaitu sebesar 0.319.

Variabel latar belakang pendidikan ternyata mempunyai hubungan terbesar dibandingkan variabel lain $\left(r_{p}=0.401\right)$. Dengan menggunakan uji t hasilnya menunjukkan bahwa variabel latar belakang pendidikan mempunyai hubungan yang signifikan terhadap pemahaman praktisi BMT terhadap PSAK No. 59 Akuntansi Perbankan Syari'ah pengakuan dan pengukuran produk finding meski hubungannya agak rendah. Adanya hubungan antara latar belakang pendidikan dengan pemahaman sangat dimungkinkan, karena berdasarkan distribusi frekuensi, sekitar 58.3\% responden berlatar belakang ekonomi. Background pendidikan yang sesuai dengan bidangnya, akan lebih memudahkan dalam mempelajari dan memahami istilah-istilah yang dipakai dalam PSAK 59. Tetlebih lagi, apabila hal ini didukung oleh umur responden yang masih dalam usia produktif (yaitu usia 20 sampai 30 tahun), serta lama bekerja dan frekuensi mengikut pelatihan yang cukup. Dengan kata lain, apabila responden tidak memiliki ketrampilan dan pengetahuan dasar yang diperlukan (latar belakang pendidikannya tidak sesuai dengan bidang pekerjaannya), maka akan menimbulkan. kesulitan dalam menangkap materi. Sehingga menyebabkan kualitas dan kuantitas penyerapan materi (pemahamannya) tidak seperti yang diharapkan.

Bila dilakukan crosstabs antara variabel latar belakang pendidikan dengan tingkat pemahaman, tidak ditemukan responden yang mempunyai tingkat pemahaman rendah, dan hanya $4.2 \%$ responden yang mempunyai tingkat pemahaman sedang. Sedangkan dari kelompok tesponden yang berlatar belakang sarjana (S1), Diploma 3 dan strata 2 (S2) seluruhnya mempunyai tingkat pemahaman tinggi terhadap PSAK 59 pengakuan dan pengukuran produk funding. Sedangkan untuk kelompok responden yang berlatar belakang SMA sebanyak $86.9 \%$ responden mempunyai tingkat pemahaman tinggi dan $13.4 \%$ responden mempunyai tingkat pemahaman sedang.

Variabel umur juga mempunyai hubungan dengan pemahaman praktisi BMT tethadap PSAK 59 pengakuan dan pengukuran produk funding $\left(r_{p}=0.361\right)$. Dengan 
menggunakan uji thasilnya menunjukkan bahwa variabel umur mempunyai hubungan yang signifikan tethadap pemahaman praktisi BMT terhadap PSAKNo. 59 Akuntansi Perbankan Syari'ah pengakuan dan pengukuran produk funding meski hubungannya rendah. Dari distribusi frekensi diketahui bahwa, sebagian besar responden berusia antara 20 sampai 30 tahun (52.1\%), dan tesponden yang berusia 31 sampai 40 tahun (41.7\%). Bila dilakukan crosstabs antara variabel usia dengan tingkat pemahaman, maka pada kelompok umur 20 sampai 30 tahun sebanyak $91.9 \%$ responden berada pada tingkat pemahaman yang tinggi dan $8.1 \%$ pada level sedang. Sedangkan pada kelompok umut lainnya, semua responden berada pada level pemahaman tinggi.

Tingginya tingkat pemahaman responden pada usia 20 sampai 30 tahun, yang mana pada rentang waktu ini merupakan usia yang produktif, merupakan suatu fenomena yang menarik. Katena, mengingat atas landas usia, daya kecerdasan seseorang akan meningkat terus dan mencapai titik optimal antara 20 sampai 30 tahun. Usia 30 sampai 60 akan mengalami penurunan dan akan menurun tajam pada usia setelah 60 tahun $^{31}$ Pada usia sekitar 20 sampai 30 tahun bisa dikatakan kondisi fisiologisnya maksimal. Aspek fisiologis ini meliput meliputi kondisi umum jasmani dan tonus (tegangan otot) yang menandai tingkat kebugaran organ-organ tubuh dan sendi-sendinya, sehingga dapat mempengaruhi semangat dan intensitas sesseorang dalam menangkap materi pelajaran.

Usia seseorang yang tergolong lanjut ataupun yang terlalu dini untuk mengikuti suatu materi pembelajaran dapat mengurangi kualitas ranah cipta (kognitif) sehingga materi yang dipelajarinya pun kurang atau tidak berbekas. Selain itu semakin meningkatnya usia seseorang, kemampuan mendengarkannya semakin berkurang. Pada usia sekitar 20-an tahun seseorang dapat mendengarkan dari sumber suara antara 8 sampai 10 meter. Setelah menginjak usia 40-an tahun ia hanya dapat mendengarkan dari jarak sekitar 5 meter $^{32}$

Variabel lain yang juga mempunyai hubungan dengan pemahaman adalah variabel lama bekerja di BMT $\left(r_{p}=0.326\right)$. Dengan menggunakan uji thasilnya menunjukkan bahwa variabel lama bekerja mempunyai hubungan yang signifikan terhadap pemahaman praktisi BMT terhadap PSAK No. 59 Akuntansi Perbankan Syari'ah pengakuan dan pengukuran produk funding meski hubungannya rendah. Selain itu, sesuai hasil angket, responden terbanyak bekerja di institusi BMT antara 3 sampai

${ }^{30}$ Lihat dalam Husaini Usman dan R. Pumomo Setiady Akbar, Pengantar, hal 253

${ }^{31}$ Rosjidan, dkk, Belajar dan Pembelajaran, (Malang: FIP Universitas Negeri Malang, 2001), hal. 12.

${ }^{32}$ Ibid., hal. 10. 
5 tahun sebanyak 31.3\%. Kemudian responden yang bekerja antara 1 sampai 3 tahun juga sebanyak $31.3 \%$, responden yang bekerja antara 5 sampai 7 tahun sebanyak 10 responden $(20.8 \%)$, dan responden yang bekerja lebih dari 7 tahun sebanyak 8 responden $(16.7 \%)$.

Bila dilakukan crosstabs antara variabel lamanya bekerja dengan tingkat pemahaman, tidak ditemukan adanya responden yang rendah tingkat pemahamannya. Pada kelompok responden kurang dari 3 tahun, 86.6\% responden berada pada level tinggi, sedangkan $13.4 \%$ berada pada kategori sedang. Sedangakan responden pada kelompok umur lain seluruhnya mempunyai tingkat pemahaman tinggi.

Tingginya tingkat pemahaman responden pada responden yang bekerja antara 3 sampai 5 tahun mengindikasikan bahwa responden sebenarnya sudah cukup memahami dasar-dasar teori maupun praktek dari pengakuan dan pengukuran produk funding ini. Meskipun usianya sudah diluar masa produktif dan latar belakang pendidikannya kurang sesuai, namun bila responden sudah cukup lama mengenal BMT maka bukan tidak mungkin responden akan memahami pekerjaannya.

Variabel lain yang juga mempunyai hubungan terhadap pemahaman adalah frekuensi responden mengikuti pelatihan atau seminar $\left(r_{p}=0.319\right)$. Dengan uji $t$ atas koefisien korelasi parsial diketahui bahwa frekuensi mengikuti pelatihan mempunyai hubungan yang signifikan terhadap pemahaman praktisi BMT terhadap PSAK No. 59 Akuntansi Perbankan Syari'ah pengakuan dan pengukuran produk funding meskipun hubungannya rendah.

Dari distribusi frekuensi diketahui bahwa $43.8 \%$ responden mengikuti pelatihan sekitar 1 sampai 3 kali Kemudian disusul dengan tesponden yang mengikuti pelatihan sekitar 4 sampai 6 kali sebanyak 33.3\%, responden yang mengikuti pelatihan sekitar 7 sampai 9 kali sebanyak $10.4 \%$, dan responden yang mengikut pelatihan lebih dari 9 kali sebanyak $12.5 \%$. Bila frekuensi pelatihan dikaitkan dengan tingkat pemahaman maka pada kelompok responden yang mengikuti pelatihan 1 sampai $3 \mathrm{kali}, 9.6 \%$ responden berada pada tingkat pemahaman sedang dan $90.4 \%$ berada pada tingkat pemahaman tinggi. berada pada kategori tinggi. Sedangkan responden pada kelompok lain selurubnya mempunyai tingkat pemahaman tinggi.

Minat dan motivasi merupakan satu diantara banyak faktor yang termasuk aspek psikologis yang dapat mempengaruhi kualitas dan kuantitas pembelajaran seseorang. ${ }^{33}$ Jadi, frekuensi mengikuti seminar dan pelatihan-pelatihan memang akan menambah pengetahuan dan pemahaman (penguasaan materi) para praktisi BMT terhadap PSAK 
59. Ditambah lagi, berdasar hasil wawancara dengan responden, sebagian besar mengetahui keberadaan PSAK 59 memang karena mengikuti pelatihan-pelatihan atau seminar-seminar.

\section{E. Penutup}

Responden yang merupakan praktisi BMT anggota Puskopsyah Daetah Istimewa Yogyakarta yang terdiri dari manajer dan staf akuntansinya, pada umumnya mempunyai tingkat pemahaman yang tinggi terhadap pengakuan dan pengukuran produk funding PSAK No. 59. Berdasarkan hasil angket yang disebarkan, responden yang berada pada kategori tinggi ini mencapai $95.8 \%$, sedangkan sisanya $4.2 \%$ berada pada kategori sedang.

Berdasarkan hasil dari uji analisis hubungan, antara variabel bebas dengan variabel terikat ternyata mempunyai hubungan dengan pemahaman tesponden terhadap PSAK 59 pengakuan dan pengukuran produk funding $(R=0.682)$. Berdasarkan uji statistik koefisien korelasi ganda hasilnya menunjukkan bahwa semua variabel bebas yang digunakan dalam penelitian ini, secara bersama-sama mempunyai hubungan yang signifikan terhadap variabel terikat. Sedangkan berdasarkan analisis korelasi parsial, variabel bebas yang mempunyai hubungan paling erat terhadap pemahaman adalah latar belakang pendidikan, kemudian disusul faktor usia, lama bekerja dan frekuensi mengikuti pelatihan. 


\section{DAFTAR PUSTAKA}

Adnan, Akhyar "Kritik atas Konsep Akuntansi Keuangan Lembaga Syari'ah Mikro". Workshop Merancang Format Akuntansi Keuangan Bagi Lembaga Keuangan Mikro Syariab di Hotel Inna Garuda-Yogyakarta tanggal 9-12 Agustus 2004 oleh Pusat Pengembangan Ekonomi (PPE) Universitas Muhammadiyah Yogyakarta dan BMT Hidayatul Muamalah Wonogiri.

Faisal, Sanapiah. 2005. Format-format Penelitian Sosial. Jakarta: Radja Grafindo Persada.

Harahap, Sofyạn Syafri. 1999. Akuntansi Islam. Jakarta: Bumi Aksara.

Hasan, Iqbal. 2005. Analisa Data Penelitian Dengan Statistik. Jakarta: Bumi Aksara. Horngren, Charles T. 1996. “Accounting 3th Edition”. Alih Bahasa Thomas H. Secokusumo. Pengantar Akuntansi (Buku 1). Jakarta: Salemba Empat.

Ikatan Akuntan Indonesia, 2003. Pernyataan Standar Akuntansi Keuangan (PSAK) No. 59 Akuntansi Perbankan Syari'ab.

Ilmi, Makhalul. 2002. Teori dan Praktek Lembaga Mikro Keuangan Syariah. Yogyakarta: UII Press.

Institute of Islamic Banking and Insurance. 1994. Accounting Issues in Islamic Banking. London.

Muhammad. 2002. Pengantar Akuntansi Syariah. Jakarta: Salemba Empat.

Muhammad. 2005. Pengantar Akuntansi Syariah. Edisi 2 (Revisi). Jakarta: Salemba Empat.

Mursyidi. 2003. Akuntansi Zakat Kontemporer. Bandung: Remaja Rosdakarya.

Ratmono, Dwi. Pengungkapan Islamic Values Dalam Pelaporan Keuangan Bank Syari'ah Paradigma Akuntansi Syariab Filosofis Teoritis dan PSAK 59. Makalah. Prosiding Simposium Nasional Sistem Ekonomi Islam II. Pusat Pengkajian Bisnis dan Ekonomi Islam Universitas Brawijaya Malang, 28-29 Mei 2004.

Rosjidan dkk. 2001. Belajar dan Pembelajaran. Malang, FIP Universitas Negeri Malang. Sigit, Soehardi. 1999. Pengantar Metodologi Penelitian untuk Sosial Bisnis Manajemen. Yogyakarta: Lukman Offset.

Sugiyono. 2003. Metode Penelitian Administrasi. Bandung, Alfabeta.

Triyuwono, Iwan. Akuntansi Syari'ab dan Koperasi Mencari Bentuk dalam Metafora Amanah. Jurnal Akuntansi dan Auditing Indonesia. Volume 1 No.1. Mei 1997. 
Triyuwono, Iwan. Metafora Zakat dan Shari'ab Enpterpise Theory sebagai Konsep Dasar dalamMembentuk Aksntansi Syari'ab. Jumal Akuntansi dan Auditing Indonesia. Voleme 5 No. 2. Desember 2001.

Umar, Husein. 1998. Riset Akuntansi. Jakarta: Gramedia Pustaka Utama.

Usman, Husaini dan R. Purnomo Setiady Akbat. 1995. Pengantar Statistika. Jakarta: Bumi Aksara.

Warren, Carl S. et. al. 2005. "Accounting 21th Edition". Alih Bahasa. Aria Farahmita, dkk. Pengantar Akuntansi Edisi 21. Buku 1. Jakarta: Salembat Empat.

Widodo, Hertanto.2000. Pedoman Akuntansi Syariat Panduan Praktis Operasional Baitul Mal wat Tamwil. Bandung: Mizan.

Yaya, Rizal. "Mengkritisi Konsep Akuntansi Keuangan Bagi Lembaga Keuangan Mikro Syariah". Workshop Merancang Format Akuntansi Keuangan Bagi Lembaga Ketangan Mikro Syariab di Hotel Inna Garuda-Yogyakarta tanggal 9-12 Agustus 2004 oleh Pusat Pengembangan Ekonomi (PPE) Universitas Muhammadiyah Yogyakarta dan BMT Hidayatul Muamalah Wonogiti.

www.republika.co.id. 